folk/ed. Derg, 2021; 27(4)-108. sayı

DOI: $10.22559 /$ folklor1971

\title{
Oryantal Dans, Kadın Deneyimleri, Sahne ve Dramaturji: Bir Araştırma Hikâyesi
}

\section{Belly Dance, Women's Experiences, Stage and Dramaturgy: A Research Story}

\section{Berna Kurt ${ }^{*}$}

Öz

Bu çalışmada, son üç yıldır, üç farklı ülke ve beş farklı şehirde, çok farklı deneyimlere sahip kadınlarla birlikte gerçekleştirdiğim oryantal dans araştırmalarımı değerlendiriyorum. Araştırmanın araştırmacı olarak üzerimdeki etkisini değerlendirebilmek için, öncelikle kronolojik bir anlatı inşa ediyor ve araştırma öncesinde bedenselliğimi ve dansla kurduğum ilişkiyi tarihselleştiriyorum. Daha sonra araştırma sürecinde dansçı-araştırmacı, dramaturg, dans öğrencisi vd. olarak edindiğim kişisel deneyimleri, sanatsal ve bilimsel araştırmalar ya da bedensel ve zihinsel deneyimler gibi ikilikler kurmadan, üstlendiğim farklı rolleri gözden geçirerek inceliyorum.

Çalışmamda, kişisel deneyimlerim birincil kaynaklarımı, feminist yöntemi tartışan ve farklı kadınların oryantal dans deneyimlerini inceleyen araştırmalar da ikincil

Geliş tarihi (Received): 13-04-2021 - Kabul tarihi (Accepted): 28-09-2021

* Prof.Dr., İstanbul Aydın Üniversitesi Sanat ve Kültür Yönetimi. (Istanbul Aydın University Art and Culture Management) bernakurt@aydin.edu.tr. ORCID 0000-0002-9937-1308 
kaynaklarımı oluşturuyor. Değerlendirmemi, feminist yöntemin konumlandırılmış bilgi, özdüşünümsellik, kadın deneyimlerini temel alma, kadınlarla birlikte ve güçlenmek için çalışma gibi ilkeleri etrafinda yapıyorum. Son olarak, araştırma sürecinin araştırmacı olarak üzerimdeki etkisini analiz ediyor; gündelik hayatta ve performans bağlamlarında bedenimle ve dansla kurduğum ilişkideki değişimi değerlendiriyorum. Bu değişimi, farklı coğrafya ve tarihselliklerdeki başka kadınların oryantal dans deneyimlerini tartışan akademik literatürle ilişkilendirerek, kişisel hikâyemi daha geniş bir bağlama oturtmaya çalışıyorum.

Anahtar sözcükler: feminist yöntem, özdüşünümsellik, toplumsal cinsiyet, oryantal dans, göbek dansı

\begin{abstract}
In this study, I reflect upon my belly dance research that I have been conducting since the last three years in three different countries and five different cities, with women having various experiences. To be able to analyze the effect of this research on myself as a researcher, I construct a chronological narrative which first focuses on my corporeality and my relation with dance before this research. I continue to investigate my personal experiences as dancer-researcher, dramaturg, dance student etc. in the research process without creating dualities between artistic and scientific research or corporeal and intellectual experiences.

My personal experiences constitute my primary resources in this study. I also discuss some secondary sources on feminist methodology and different women's belly dance experiences. I make an analysis on the basis of some principles of feminist methodology like situated knowledge, self-reflexivity, the focus on women's experiences, working with women for empowerment. I also reflect upon the effect of the research on myself as the researcher, especially the change in my corporeal expression in daily life and within performance contexts. To analyze my personal experience in a wider context, I relate this change in my corporeality with academic belly dance literature which discuss other women's belly dance experiences in various historical and geographical contexts.
\end{abstract}

Keywords: feminist methodology, self-reflexivity, gender, belly dance, oriental dance

\title{
Extended summary
}

As a social scientist with a dance background, I mostly make research on the social, historical and political contexts of dance performances and choreographies. My research for artistic and academic purposes converge and enrich each other. Accordingly, I avoid the dualities between artistic and scientific research or corporeal and intellectual experiences.

Gender inequalities in dance production and daily life have always been one of my primary problematics. In this study, I focus on my belly dance research with a feminist perspective. I use qualitative research techniques of feminist methodology with which I can share my experience, knowledge and emotions. I reflect upon the research that I have been 
conducting since the last three years in three different countries and five different cities, with women from very different backgrounds.

I analyze my personal experience on the basis of some principles of feminist methodology: awareness of the situated knowledge, self-reflexivity, the focus on women's experiences, working with women for empowerment. I also reflect upon the effects of the research on myself as the researcher, especially the change in my corporeality in daily life and within performance contexts. To be able to analyze those effects, I construct a historical framework of my experience in dance and movement. In a chronological narrative, I firstly focus on my corporeality and my relation with dance before this research on belly dance. I refer to my free dancing childhoold, my later more restricted bodily expression partly related to my gender socialization process. Afterwards, I continue to investigate my personal experiences as dancer-researcher, dramaturg, dance student etc. in my research process on belly dance.

This research has multidimensional aspects which consist of feminist and post-colonialistreadings on belly dance, discussions of the personal experiences of gender inequalities, making interviews, watching performances, learning belly dance from different teachers, listening to various musical recordings, improvising on dance and music with women from different countries, ages, backgrounds and sexual orientations. The impact of this research on me as a researcher was also multidimensional, as it was conducted in different countries, with people from a wide variety of geographies and identities. This intercultural study made me rethink about my own plural identities, experiences and the working conditions and cultural codes in my native country, Turkey. Since the dramaturgical work is mostly based on the perception of the audience in different contexts, my observations and personal experiences in various cities came into prominence. My first-hand observations of different artists' modes and conditions of production inevitably enabled me to make comparisons and develop my perspective as an artist and researcher working in cultural sector.

In the research process, I realized that my belly dance practice contributed to the liberation of my bodily expression. I began to move my body more easily, freely and self-confidently in daily life and in performative contexts. While improvising, I realized that I have a much wider movement repertoire and I can easily move new parts of my body that I couldn't do before.

Such personal experiences constitute my primary resources in this study. I also discuss some secondary sources on different women's belly dance experiences. To analyze my personal experience in a wider context, I relate my experience with the findings of the belly dance literature which discuss women's belly dance experiences in various historical and geographical contexts.

Most of the research focused on belly dancing women express the "positive" effects of belly dance courses in different aspects. I found that my experiences are similar to those of many other women -including the participants of the same dance courses with me in Istanbul/ Turkey and the Western women discussed in academic literature on belly dance.

Most of this literature refers to the historical context of feminist movements in Western countries in the 1970's. They state that in this period, predominantly white and middle-class 
women in Western Europe and North America were interested in belly dancing and feminist women redefined belly dance as a symbol of liberation. This dance has been correlated with body acceptance, physical fitness, personal growth, sisterhood and spirituality.

Although Turkey is accepted as one of the main geographies of this dance genre, we do not observe that belly dance or any other dance genre has become popular in the feminist movement that has developed since the 1980's. However, regardless of history or geography, we see that women-only dance learning environments provide a safe and supportive atmosphere without the judgmental attitudes associated with the male gaze. Such contexts make it easier for women to define their own relationship with their bodies and provide some opportunites for empowerment.

Belly dance still offers very rich opportunities for postcolonial feminist studies. Alternative performative, pedagogical and academic approaches can be created in this field to provide some tools of empowerment for a wider community of people.

\section{Giriş}

Yaklaşık üç yıldır oryantal dansla ${ }^{1}$ ilgili uygulamalı ve kuramsal çalışmalar yürütüyorum. Dans geçmişi olan bir araştırmacı olarak, sanatsal ve bilimsel araştırma süreçlerim çoğu zaman içe içe geçti, birbirini besleyip zenginleştirdi. Farklı ülke ve şehirlerde, farklı hedeflerle yürüttüğüm bu çalışmaların birçoğunu yine çeşitli ülkelerden birçok kadınla ve kendini ikili cinsiyet kimlikleriyle tanımlamayan kişilerle birlikte gerçekleştiriyorum. Oryantal dans araştırmalarımı merkeze alacağım bu çalışmada, öncelikle dansçı-araştırmacı, dramaturg, dans öğrencisi gibi kimlikler üstlenerek edindiğim kişisel deneyimi kronolojik bir akış içerisinde değerlendireceğim. Daha sonra, bu deneyimi, farklı kadınların oryantal dans deneyimleriyle birlikte ele almaya çalışacağım. Kişisel deneyimlerim birincil kaynağımı, oryantal dans alanındaki literatür ile feminist yöntem tartışmaları da ikincil kaynaklarımı oluşturacak.

Analizimi kendi "deneyim, bilgi ve duyguları(mı) paylaşabileceğim nitel araştırma teknikleri”nden biri olan feminist yöntemi kullanarak yapmaya çalışacağım. Feminist yöntemsel yaklaşımlarda temel hedefler olan "gündelik hayatın ve toplumsal cinsiyetlenmiş ilişkilerin analizi" (Öztan, 2015: 286, 287) ve güçlenme, dans ve akademi alanlarında benim de temel hedeflerim arasinda.

Dans hareketini toplumsal, kültürel ve siyasal bağlamlarla ve toplumsal cinsiyet kimliğiyle ilişkili olarak incelerken, “iki bilgi türü”nü bir araya getirmeye çalışacağım: “1) hipotezler oluşturan, kuramları inceleyen, insanların eylemlerini anlamlandırmaya çalışan entelektüel bilgi, 2) bir grup insanla birlikte zaman geçirmenin ortaya çıkardığı deneyimsel bilgi” (Grau, 2007: 2). Değerlendirmeye geçmeden önce, inceleyeceğim dans türü olan oryantal dansla ilgili kısa bir tarihsel çerçeve oluşturmaya çalışacağım.

Oryantal dansın Kuzey Afrika ve "Ortadoğu” olarak tanımlanan coğrafyada ortaya çıktığı kabul edilmektedir. Osmanlı İmparatorluğu'nun klasik döneminden itibaren şehirlerde seyirlik bir tür olarak var olduğu bilinmektedir. Türkiye' deki yerleşik halk dansı ya da "folklorik" dans türlerinden biri olan çiftetelli bu dansın yerel versiyonlarından biri olarak kabul 
edilmektedir. 16. yüzyıldan 19. yüzyıla kadar ağırlıklı olarak gayrımüslim kadın (çengi) ve erkek (köçek) profesyonel dansçılar tarafından, sarayda, kamusal saray şenliklerinde, kahvehanelerde ve seçkinlerin konaklarında icra edilmiştir (And, 1976: 142-146; Potuoğlu-Cook, 2006: 651; Öztürkmen, 2001: 143, 2003: 40, 2011: 287-288). Toplumsal yapıdaki değişimler, özellikle gayrimüslim nüfusunun azalması ve bu dans türünü destekleyen Osmanlı seçkinlerinin iktidarının sona ermesiyle birlikte bir dönem sürekliliğini kaybetmiştir. Yeni cumhuriyet rejiminin ilk yıllarında cinsellikle ve "kötü kadın"larla özdeşleştirilerek itibar kaybetmiş olan dans, ancak turizmin yükselişiyle birlikte yeniden popülerlik kazanmıştır (Öztürkmen, 2001: 143, 2011: 288). Halen eğlence ortamlarında hem seyirlik hem de özellikle kadınların katılım gösterdiği bir sosyal dans türü olarak var olmaya devam etmektedir.

Oryantal dans, günümüzde, dünyanın birçok yerinde, farklı toplumsal cinsiyet kimlikleri ve cinsiyet yönelimlerine sahip kişiler tarafından icra edilmektedir. Çalışmanın son bölümünde değinileceği şekilde, farklı coğrafyalarda özellikle kadınlar tarafından sahiplenilmiş bir küresel dans türü haline gelmiştir.

$\mathrm{Bu}$ dans türüyle ilgili değerlendirmeye geçmeden önce, öncelikle hem kendimi konumlandırmak hem de araştırma sürecinin araştırmacıya etkisini değerlendirebilmek adına, araştırma öncesinde dansla kurduğum ilişki ile araştırma sürecindeki deneyimlerimi kronolojik bir akış içerisinde aktaracağım.

\section{Araştırma süreci}

Çocukken, yaz aylarını annemin ve babamın memleketi olan Sinop'ta geçirir, köçek ekiplerinin katıldığg gelin alma, sünnet ve dügünleri izlerdik. O zamanlar akraba dügünlerinin güzel 'oynayan' kız çocuklarından biriydim. Dans etmeye çok meraklıydım. Düğünlerde yorulana kadar oynar, evde olduğum zamanlarda da teybe kaset koyup dans ederdim.

1980’li yılların ortalarında henüz bir ilkokul öğrencisiyken halk danslarıyla tanıştım. Böylelikle orta sınıf bir ailenin çocuğu olarak o yıllarda asla sahip olamayacağım bir imkâna kavuştum ve daha dokuz yaşında yurtdışına çıktım. İlkokul ekibi olarak uluslararası bir yarışmaya katılmış, Portekiz'e altı gün süren otobüs yolculuğumuz esnasında Venedik’te gondola binmiş, İspanya'da boğa güreşi seyretmiştim. O yaşlardaki bir kız çocuğu için oldukça ilginç olan bu deneyimleri yaşamamı sağlayan şey yine dans olmuştu.

Aynı yıllarda aldığımız ilk renkli televizyonda Devlet Halk Dansları Topluluğu'nun çiftetelli koreografisini seyrettiğimi hatırlıyorum. Özellikle kadın dansçılara hayran olmuştum; onları rol modeli olarak kabul ediyor, performanslarını özenerek taklit ediyordum. Sahneye çıkmayı da çok sevmiştim ama yine de sonraki yıllarda dansın hayatımın bu kadar merkezinde olacağını henüz bilemezdim.

Ergenlik yıllarımda bu dans pratiğim sekteye uğradı. Fiziksel olarak fazlasıyla erken gelişen, göğüslerinin dikkat çekmemesi için kambur bir postür edinen birçok kız çocuğu gibi ben de artık dans pistlerine fırlamaz olmuştum. Yaşadığımız coğrafyanın, içinde yetiştiğimiz tarihselliğin ve toplumsallığın içinde benim gibi şehirli, iyi okuyan kız çocuklarına biçilen 
rol, fiziksel olarak dikkat çekmemek, hem edepli hem de akıllı olmaktı. Bu rolleri layıkıyla yerine getirdiğimi söyleyebilirim. Çok çalıştım; disiplinli ve sorumluluk sahibi bir memur çocuğu olarak mükâfatım da Türkiye'nin en iyi devlet okullarında okuyabilmek oldu.

Üniversiteye başladığımda, eve kapanarak çalışmak zorunda olmanın acısını çıkardım. Birçok öğrenci kulübüne birden üye olarak, etkinlikten etkinliğe koştum. İlk yılımda belki de hayatımın en sosyal dönemlerini yaşadım. En önemlisi de, dansa geri dönme şansı buldum. Yine bir öğrenci kulübünde halk dansları öğreniyor, çalıştırıyor, koreografi yapıyor, araştırıyor, yazıyor, çeviriler yapıyordum. Aslında ilk tercihimi kazanmıştım; çok da sevdiğim Siyaset Bilimi bölümünde okuyordum ama dans tüm boyutlarıyla hayatımın merkezi olmuştu ve ileride mesleki seçimlerimi belirleyecek bir konuma gelmişti.

O yıllarda farklı halk dansı formlarıyla birlikte çağdaş dansı, fiziksel oyunculuk tekniklerini eklektik bir biçimde bir araya getiren, bir anlamda disiplinler arası sanat çalışmaları yürütüyorduk. Birçok dans türünü rahatlıkla icra eden bir bedenselliğe sahiptim. Ancak ilk kez 9/8'lik Çingene/Roman danslarını çalışmaya başladığımda, bedenimde anlam vermediğim bir tutukluk hissettim. Teknik olarak çok kolaylıkla yapabileceğim hareketleri yap(a) maz durumda buldum kendimi. Hareketleri 'doğru' yapıyordum ama fazlasıyla ölçülü ve zarif hareketlerle. Adeta, çocukken hayran kaldığım, bugün ise fazla stilize bulduğum Devlet Halk Dansları Topluluğu dansçıları gibiydim. Benim gibi şehirde büyümüş, Trakya'yla hiç teması olmamış, 'fazla' entelektüel birçok kadın arkadaşım da aynı durumdaydı. Daha 'rahat' dans edenlerimiz de vardı. Aramızdaki farkı anlamlandıramıyordum. Dansı kendilerinden öğrenmeye çalıştığımız, düğünlerine giderek karşılıklı oynadığımız Roman kadınları kadar özgür bir beden kullanımına kavuşmak o zamanlar için imkânsız görünüyordu bana.

O yıllarda üniversiteli feminist dansçılar olarak dans alanındaki cinsiyetçi işbölümlerini kırmak ve alternatif sahneler üretmek için çaba sarf ediyorduk. Yerel danslardaki tavır ve otantiklik meselelerine hep soru işaretleriyle bakmakla birlikte, zamanla 'kadın dansı' olarak kabul gören bazı türlere odaklanmaya karar vermiş, birkaç sahne denemesi de yapmış ama daha ileri gidememiştik. O yıllarda sahneye dair başka birçok 'mesele'm daha vardı. Bu bedensel rahatlık farkını anlamlandırabilme ve kendimdeki tutukluğu aşma şansını çok bulamadım. Üç sene önce, tamamen bir tesadüf sonucunda, oryantal dansla tanıştım. Yine kadın dansı olarak kabul edilen bu dansı ögrenmeye başlayınca, hem bedensel ifade tarzımda bir eşiği aşma hem de benim için çok yeni, zevkli ve verimli bir araştırma alanını keşfetme şansına kavuştum.

\subsection{We'R'Dansöz misafir sanatçı programı araştırması: (Bonn)}

Oryantal dansla tanışma hikâyem, halen çok sevdiğim bir dostum ve çalışma arkadaşım olan Tümay Kılınçel'le bir araya gelişimle başlıyor. Berlin'de yaşayan bir çağdaş dans sanatçısı olan Tümay 2016 yılında İstanbul'a geldiğinde tanıştık. İlk buluşmamızda beni başvuracağı bir misafir sanatçı bursuna davet etti. Böylelikle 2018 yazında, hiç tanımadığım başka iki sanatçıyla, Baly Nguyen ve Hiba Shammout'la birlikte Flausen + Young Artists in Residence misafir sanatçı programına katılmış oldum. Bonn'da bir ay süren We'R'Dansöz araştırma projesi sayesinde, oryantal dans üzerine çalışmaya başlamış oldum. 
Bu dans türü üzerine okuma, pratik yapma, video seyretme, müzik dinleme ve tasarlama, tartışma ve notlar alma gibi farklı boyutları olan bu süreçte, Mısırlı performans sanatçısı, araştırmacı ve yazar Nora Amin bize danışmanlık yaptı. Amin'den talep ettiğimiz kuramsal ve uygulamalı atölyeler esnasında, doğaçlama çalışmaları da yürüttük. Oryantal dansa yönelik feminist ve sömürgecilik karşıtı bir yaklaşım geliştirmenin yollarını aradık.

Benim dansçı-araştırmacı konumunda olduğum bu kolektif araştırma deneyimi hem Tümay'la birbirimizi daha iyi tanımamızı sağladı hem de daha sonraki ortak çalışmalarımıza vesile oldu. Çok yoğun ve istekli bir şekilde çalıştığım, ekip çalışmasını yürütmeye yönelik becerilerimi hatırladığım, küratöryel birtakım yeteneklerimi keşfettiğim bu bir aylık süreç kamuya açık bir performatif sunum ve sergiyle sonuçlandı. ${ }^{2}$ Prodüksiyon odaklı olmayan, kamusal paylaşımı olan bu tür bir araştırma bursu deneyimi, sanat ve kültür yönetimi alanında çalışan bir akademisyen olarak da benim için oldukça ilham verici oldu. Evime yeni bir çalışma alanıyla ve daha sonra peşine düşeceğim birçok soruyla dönmüş oldum.

\section{2. İstanbul oryantaller eğitim ve kültür derneği: (İstanbul)}

İstanbul'a döndüğümde hem bu dansı daha iyi öğrenmeye hem de yıllar sonra feminist kuram okumalarına geri dönmeye karar verdim. Öncelikle işi 'uzman'ından öğrenmek istedim. İstanbul'da dans kursu aramış ama henüz içime sinecek bir yer bulamamıştım. Çağdaş dans sanatçısı ve yaratıcı dans eğitmeni arkadaşım Lerna Babikyan'ın sosyal medyadaki bir yer bildirimi sayesinde, yine tamamen tesadüfi bir biçimde İstanbul Oryantaller Eğitim ve Kültür Derneği'nden (İstorder) haberdar oldum.

Şubat 2019'da yolum İstorder'e düştüğünde, kendimi ortalama bir dans kursunun çok dışında bir yerde bulmuştum. Kadınların birlikte dans etmenin ötesinde, birlikte zaman geçirdiği bu sosyalleşme, paylaşım ve dayanışma ortamı çok ilgimi çekmişti. Çok kısa bir süre içinde, yeni ve meraklı bir dans öğrencisi olarak ben de bu ortamın bir parçası oldum. Bir süre sonra, haftada bir-iki gün düzenli gittiğim, her ders sonrasında çay, kahve eşliğinde uzunca sohbetler ettiğim bu dernekle ilgili akademik çalışma yürütmeye karar verdim. Bu kararı dernektekilerle paylaştığımda oldukça olumlu geri dönüşler aldım. Yıllardır katıldığım bütün dans derslerinin sonrasında kendim için tuttuğum notlar da zamanla saha notlarına dönüştü.

\subsection{Dansöz çağdaş dans performansı: (Frankfurt, Düsseldorf, Basel)}

2019 yılında, Tümay'ın davetiyle oryantal dansı feminist bir bakışla ele alan ilk solo koreografisi Dansöz'de dramaturg olarak çalıştım. ${ }^{3}$ İstanbul'da hazırlıklarına başladığımız, Temmuz ve Eylül aylarında Almanya ve İsviçre'de birlikte çalıştığımız Dansöz isimli bu çağdaş dans performansının ilk gösterimi Ekim 2019'da İsviçre'nin Basel şehrinde gerçekleşti.

Tümay'ın bu ilk solo koreografisi, benim de ilk uluslararası bireysel dramaturji çalışmamdı. Otobiyografik özelliklere sahip olan bu gösteri, dansçı-koreografın sahip olduğu çoklu kimliklerle ve hakim cinsiyetçi ve sömürgeci oryantal dans imgeleriyle hesaplaşıyordu. Gösterinin hazırlık süreci aslında iki kadının birlikte güçlenme süreciydi. 
Bu dönemde yaptığımız araştırma, bu alandaki akademik üretimlerime de kaynak oluşturdu. Gösterinin hazırlık sürecinde, arka plan çalışması bağlamında, bu dans türünün tanımına, tarihine ve icrasına yönelik yaptığım okumalar birçok yayında kullandığım temel kaynaklar haline geldi.

\subsection{Yılbaşı dansözü eşlikçiliği (İstanbul)}

Yine 2019 yılının son gününde, Tümay’ın İstorder'in yılbaşı dansözlerinden biri olarak üç farklı yerde sahneye çıkma sürecine eşlik ettim. Bir çağdaş dansçı olarak oryantal dansçılık/dansözlük deneyimi kazanmak isteyen arkadaşıma eşlik ederken, yer yer menajer gibi davranmak durumunda kaldım. Kendisinin çok kısa bir sürede, üç farklı mekâna ulaşmasını sağladım. Performans öncesinde mekân sorumluları ve çalışanlarıyla iletişime geçerek, dansa eşlik edecek olan kayıt müziği ve performans ortamlarını kontrol ettim. Tümay’ın giyinmesine ve hazırlanmasına yardımcı oldum. Performans esnasında da süre ve mekân kullanımı vb. konusunda ona destek oldum. Bahşişleri ya da ödemeleri toplayıp taşıma gibi sorumlulukları da yerine getirdim. Daha önce hiç yapmadığım bu tür işleri, spontane bir şekilde, farklı kimliklere bürünerek gerçekleştirdim. Geceyi fotoğraf ve video kayıtlarıyla belgeledim. Böylelikle sahnenin arka planına yönelik ilk elden verilere ulaşma şansı elde ettim. Bu deneyimi 2020 yılbaşında da tekrar yaşamak istesek de, ne yazık ki o yıl ortaya çıkan Covid-19 salgını yüzünden gerçekleştirme şansı bulamadık.

Dans derslerine başladıktan yaklaşık bir sene sonra ortaya çıkan bu küresel salgın yüzünden, derneğe gitmeye uzun bir süre ara vermek ve yine o süreçte başlayan çevrimiçi derslere katılmak durumunda kaldım. Derneğin dönem dönem yasaklar yüzünden kapanıp tekrar açılması, derslere her yaz dönemiyle birlikte azalan katılımı iyice düşürmüştü. Çevrimiçi ortamla sinırlı kalan dersler boyunca, dernekten hocalarımla ve derslere devam eden sınırlı sayıda katılımcıyla iletişimi ancak dijital ortamda gerçekleştirebildim. Bu süreçte okumalara ve yayınlara ağırlık verdim. Ayrıca yeni bir dramaturji projesi için hazırlıklara başladım. Kasım sonunda Berlin'de sergilenecek olan, Tümay’ın bu sefer yönetmenlik yapacağı, yine oryantal dans temelli çağdaş bir toplu koreografi için çalışma yürüteceğiz.

Makalenin ilerleyen bölümlerinde, araştırmamda kullandığım feminist yöntemin bazı ilkelerini araştırma sürecimle birlikte ele almaya ve araştırmanın araştırmacı olarak benim üzerimdeki etkisini değerlendirmeye çalışacağım.

\section{Feminist bir araştırma yürütmek}

Feminist yöntem olarak tanımlanabilecek kendine özgü bir alan olup olmadığı, araştırmacıların üzerinde uzlaştığı bir konu değildir. Hem bu tür bağımsız bir alanın varlığını savunan hem de diğer sosyal bilim yöntemlerini esnek ve disiplinler arası bir yaklaşımla bir araya getirdiğini düşünen birçok araştırmacı bulunmaktadır. Ece Öztan feminist araştırmaları diğer sosyal bilim araştırmalarından farklı kılan dört temel ortak özellik sıralamaktadır: 
“1. Feminist bir bakış açısının kabulü ve toplumsal cinsiyet ilişkilerine odaklanmak,

2. Geleneksel bilimsel yöntemlerde vurgulananın aksine gündelik hayat ve kişisel deneyimlere verilen önem,

3. Araştırmacı ve araştırılan arasındaki hiyerarşinin reddedilmesi,

4. Kadınların özgürleşimi ve toplumsal cinsiyet eşitsizliklerinin ortadan kaldırılmasının araştırma hedefleri arasında yer alması" (Öztan, 2015: 277).

Feminist bir bakış açısından hareketle toplumsal cinsiyet eşitsizliklerine odaklandığım, bunları görünür kılmaya ve eleştirmeye çalıştığım sanatsal üretimlerde, feminist hareketlerin tarihsel talepleri, kazanımları ve güncel meseleleri çoğu zaman arka planımı oluşturdu. Örneğin kimlikleri sorguladığımız sahnelerde kesişimsel bir feminist perspektifi ön planda tutarken; kadın bedenini nesneleştirmeye karşı çıkan sahnelerde, tacize dair güncel temaları, ifadeleri ve sloganları kullandık. Çoğu zaman kişisel hikâyelerimizi merkeze aldık. 1960’11 yıllardan bu yana çağdaş sanat alanlarında hakim olan perspektifi benimseyerek, süreci sonuçtan -prova sürecini nihai ürün olan koreografiden- ayırmadık. Koreografinin alternatifliğini prova sürecine de yaymak adına, çalışmalarımızı olabildiğince şeffaf, katılımcı ve demokratik bir şekilde kurgulamaya çalıştık. Bu süreçte birbirimizle, sahneleme esnasında da seyirci ile eşitlikçi bir ilişki geliştirmeyi hedefledik.

Makalenin ilerleyen bölümlerde, oryantal dans temalı araştırmalarımın tümü için geçerli olduğunu düşündüğüm feminist yöntem ilkelerini alt başlıklar halinde özetlemeye çalışacağım.

\subsection{Konumlandırılmış bilgi ve özdüşünümsellik}

Çalışma yürütürken kendi deneyimimi araştırma sürecimin temel meselesi olarak kabul edip analiz etmeye çalıştım. Feminist metodolojinin kişiselliği önemseyen, objektif bilgi anlayışını sorgulayan yaklaşımını benimseyerek, "belli bir zaman, mekân ve tarihsel güç ilişkileri kesişiminde, maddi ve söylemsel olarak konumlanmış bir pozisyondan elde edilen" konumlandırılmış bir bilgiye (Öztan, 2015: 275) sahip olduğumu hep aklımda tutmaya ve özdüşünümsel bir yaklaşım geliştirmeye çalıştım.

Özdüşünümselliği, "araştırmacının kendini bir inceleme nesnesi haline getirmesi ve kendisinin araştırmasındaki belirleyici rolünün farkında olması” olarak tanımlayan Ayla Deniz, feminist araştırmalarda, bilgi üretiminin Donna Haraway’in (2010c) belirttiği şekilde taraflılık, konumluluk, öznellik, ilişkisellik ve iktidar yüklü olmak gibi meseleler temel alınarak tartışıldığını ifade etmektedir. Araştırmacıların duygu ve düşüncelerinin araştırmaya etkisini vurgulayan özdüşünümselliğin, daha eşitlikçi ve etik bir bilgi üretim pratiği yaratmayı sağladığını belirtmektedir (Deniz, 2020: 232, 233).

Hem bu makalede hem de yukarıda aktardığım araştırma sürecinde kişisel deneyimim ile sahip olduğum kimliklerin farklı açılımlarını göz önünde tutarak değerlendirme yapmaya çalıştım. Bir feminist olarak "taraflı” kimliğimi açıkça ortaya koydum ve kendimi araştırdığım konuyla bağlantılı şekilde konumlandırmaya çalıştım. 
Koreografi, dans eğitimi ve dramaturji alanındaki meselelerim, gündemlerim, soru işaretlerim çoğu zaman akademik araştırmalara kapı açtı. Yaratıcı süreçlerde birlikte çalıştığım kadınların deneyimleri de benim için her zaman önemliydi.

\subsection{Kadın deneyimlerini temel alma}

Oryantal dansla ilgili çalışma yürütürken, Birkalan-Gedik'in (2009: 324) feminist etnografi çalışmaları için önerdiği bir çerçeve olan "kadınların egemen olduğu sanatsal formlara uzanıp kadın deneyimlerini ve üretimlerini yakalama ve gözleme" şansına kavuşmuş oldum. Kadınların egemen olduğu bir dans formu olan oryantal dans alanında hem kendimin hem de başka kadınların deneyimlerini çalışmamın merkezine aldım.

Farklı ülkelerden kadınlarla birlikte oryantal dansa dair araştırma yürüttüğümüz We'R'Dansöz programında, danışmanımız Nora Amin'den, özellikle dansın doğduğu temel coğrafyalardan biri olarak kabul edilen Mısır'daki dansçı kadınların tarihsel deneyimleri hakkında bilgi edindik. Mısır, Filistin, Türkiye, Almanya, Avusturya, Vietnam gibi çok farklı coğrafyalarla bağlantılı dansçılık ve müzisyenlik deneyimlerimizi tartıştık. Bu deneyimleri temel alarak kendi doğaçlamalarımızı yaptık ve kısa koreografilerimizi sahneledik. Dışarıdan bir gözü, seyirci beğenisini temel almadan, kendi kendimize ve "kendimiz için" dans ettiğimiz, bazen metinler de oluşturduğumuz bu çalışmalar, hem daha özgürleşmiş bir bedensel ifadenin peşine düşmenin hem de kendi sözümüzü söylemenin temel araçlarını oluşturdu.

Aynı şekilde, dramaturjisini yaptığım Dansöz solo gösterisi de kişisel deneyime dayanan, otobiyografik bir içeriğe sahipti. Dansçı-koreograf Tümay Kılınçel'in temel çıkış noktaları İzmir'de çocukken seyrettiği bir dansöze dair hatırası ile göçmen bir aileden gelen -“Almancı" olarak adlandırılan- bir kadın dansçı olarak kişisel deneyimleriydi. Bu deneyimleri alternatif bir yaklaşımla sahneye koymak için yaptığımız denemeler, yeri geldiğinde feminist hareket ve kuramlarının tarihsel deneyimleriyle temas etti.

Halen yürütmekte olduğum, oryantal dans alanındaki ilk etnografik çalışmam ise, bu dansın eğitimini alan kadınların bir araya geldiği İstanbul Oryantaller Eğitim ve Kültür Derneği ortamını temel alıyor. Birçok feminist araştırmacı gibi "kadınların somut/gündelik deneyimlerini... başlangıç noktası olarak” (Sandra Harding (1987; 1992), Donna Haraway (1991), Alison Jaggar (1989), Dorothy Smith (1987; 1990)'ten akt. Öztan, 2015: 273) aldığım bu çalışmada, saha notlarım ve yarı yapılandırılmış görüşmelerim, her yaştan, çok farklı kimliklere sahip kadınların deneyimlerini içeriyor. Bununla birlikte, bu makaleyi kendi deneyimimle sınırlı tutmaktayım. Çalışmayı kişisel bir anlatı ya da otobiyografik bir metin olmaktan çıkarmak, daha geniş bir bağlamda değerlendirme yapabilmek için de deneyimlerimi farklı kadınların oryantal dans deneyimlerini tartışan kaynaklarla ilişkilendireceğim.

\subsection{Kadınlarla birlikte, güçlenmek için çalışma}

Bugün geriye dönüp baktığımda, tüm bu çalışmaları, "kadınlar hakkında, kadınlar için, kadınlarla birlikte” yürüttüğümü fark ediyorum (Kelly ve diğ. 1995’ten akt. Erdoğan, Gündoğdu, 2020: 16). Yaklaşık yirmi beş yıl önce, feminist dans sahneleri yaratırken, kadın arkadaşlarımla birlikte güçlenmek için seçtiğim bu çerçeve aslında bugün -hem kişisel deneyimim hem 
de feminist hareket ve kuramların tarihselliği ${ }^{4}$ bağlamında- benim için tek seçenek olmaktan çıkmış durumda. Kendini ikili toplumsal cinsiyet kodlarıyla tanımlamayan bireyler ya da toplumsal cinsiyet eşitsizliklerine duyarlı, pro-feminist olarak tanımlanan heteroseksüel erkeklerle de birlikte çalışabiliyorum. Bununla birlikte, kadınlarla özdeşleştirilen bir dans formuyla ilgili çalışma yaparken, kadınlarla birlikte çalışmak kaçınılmaz bir başlangıç ilkesi oluyor.

Oryantal dansa yönelik feminist ve sömürgecilik karşıtı bir yaklaşım geliştirmek için yürüttüğümüz We 'R'Dansöz araştırması hem bu alanla tanışmak hem de alternatif yaklaşımların ilk adımlarını atmak için, dört kadınla birlikte yaşadığımız bir serüvendi. Bu süreçten beslenen ilk sanatsal ürün, Tümay'la birlikte çalıştığımız Dansöz oldu. Bu koreografinin arka planını oluşturan araştırma ve deneyimlerin bir kısmı akademik üretimlere temel oluşturdu. Şu anda birlikte üzerine çalıştığımız toplu koreografi ise, Berlin'de yaşayan, farklı cinsel yönelimlere sahip oryantal dansçıların deneyimlerini temel alıyor. Yine yerleşik oryantal dans imgeleriyle hesaplaşmak isteyen bu çalışma, bu sefer perspektifimizi genişletmenin, zenginleştirmenin ve hep birlikte güçlenmenin yollarını arıyor.

\subsection{Araştırma sürecinin araştırmacı üzerindeki etkisinin analizi}

Yukarıda özetlediğim araştırma süreci, sahne denemelerini, eleştirel okumaları, farklı öğrenme deneyimlerini ve güncel tartışmaları da içeren, çok boyutlu bir süreçti. Farklı ülkelerde, çok çeşitli coğrafya ve kimliklerden insanlarla birlikte yürütüldüğü için, araştırmacı olarak üzerimdeki etkisi de çok boyutlu oldu. Kültürlerarası boyutlara sahip olan bu çalışma, doğal olarak kendi kimliklerim, çalışma koşullarım, yaşadığım coğrafyanın kültürel kodları vd. üzerine yeniden düşünmemi sağladı. Dramaturji çalışması gösterinin sahneleneceği yerlerdeki seyirci algısını temel aldığı için, kısa süreli olarak yaşadığım farklı şehirlerdeki gözlem ve deneyimlerim daha da bir önem kazandı. Buralarda sanatçıların üretim koşullarına dair ilk elden gözlemlerim ister istemez karşılaştırmalar yapmamı ve sahip olduğum perspektifi geliştirmemi sağladı.

Bu yazının başında, araştırmaya başlamadan önce dansla kurduğum ilişkiye değinmiştim. Son yıllarda, üniversite yıllarında yaşadığım "tutukluğu" aşmış olabileceğimi hissettiren bazı gelişmeler de yaşadım. Gündelik hayatta, örneğin en yakınlarımla şakalaşırken bedenimin bu dans sayesinde daha çok hareket ettirdiğim bölümlerini kullandığımı fark ettim ve çok şaşırdım. Bedenimi daha çok gözlemledikçe, belli bir farkındalık geliştirmeye başladım. Pandemi öncesinde katıldığım kalabalık eğlence ortamlarında eskisine kıyasla daha "rahat" hareket ettiğimi, bir anlamda daha özgürce dans ettiğimi fark ettim. Hem oryantal dans çalışmaları sayesinde hem de muhtemelen yaşın ve deneyimin artmasıyla birlikte, harekete dair özgüvenimin arttığını, bedenimi daha özgürce kullandığımı hissediyorum. Başkalarının bedenime atfettiği anlamlar ergenlik dönemimde olduğu kadar belirleyici olmadıkça, kendi kimliğimi buldukça, çocukluk yıllarımdaki 'piste firlayan kız'a dönüşmenin kolaylaştığını düşünüyorum.

Gündelik hayat dışında, sahne performansı bağlamlarında, bir “dansçı” olarak da bedensel ifade olanaklarımın ciddi biçimde geliştiğini hissediyorum. Doğaçlama yaparken, artık çok daha geniş bir hareket repertuarına sahip olduğumu, bedenimde daha önce kullan(a)madığım bölümleri rahatlıkla hareket ettirdiğimi fark ediyorum. ${ }^{5}$ Bu yaşadıklarım aslında, başka birçok kadının deneyimiyle benzerlikler taşıyor. Hem dernekteki derslere katılan kadınların 
güncel deneyimleri hem de okumalarımda karşıma çıkan Batılı kadınların daha eski tarihli deneyimleri birçok ortaklıklar taşıyor. Farklı coğrafyalarda, tarihlerde, farklı kimliklere sahip kadınlar oryantal dans derslerinin 'pozitif' etkilerini farklı veçheleriyle ifade ediyorlar.

\section{Kadınların oryantal dansı: Farklı tarih ve coğrafyalar, farklı deneyimler}

Kadınların oryantal dans deneyimlerini inceleyen akademik çalışmalar tarihsel bağlam olarak 1970’li yıllarda Batılı ülkelerde gelişen feminizm ve cinsel özgürlük hareketlerine işaret ediyorlar. Bu yıllarda Batı Avrupa ve Kuzey Amerika'da ağırlıklı olarak beyaz ve orta sınıf kadınların oryantal dansa ilgi duyduğunu ifade ediyorlar. Bu yıllarda, bir zamanlar kadın bedenini nesneleştirdiği düşünülen oryantal dansı sahiplenerek bir özgürleşme sembolü olarak yeniden tanımlayan feminist kadınların, bir çeşit “oryantal dans hareketi” oluşturduğu ifade ediliyor (Shay ve Sellers-Young, 2003: 17).

Dansın bu yıllarda kazandığı popülerlik, bu dansın temel eğitiminin verildiği, "nasıl yapılır" formatında birçok kitabın ortaya çıkmasını sağlıyor. Bu yayınlar farklı birçok pedagojik işlevi birden taşıyor. Dansın sağlık ve fitness açısından faydalarını vurguluyor; alışılageldik, basmakalıp temsil ve algıları ters yüz etmeye, dansa itibar kazandırmaya çalışıyor. Tüm bu yayınlar, oryantal dansa yönelik yeni ve popüler bir Batılı söylem ortaya koyuyor. Bu söylem etrafında birleşen birçok kadın, sosyal medya ve uluslararası festivaller vb. etkinlikler üzerinden ağlar oluşturuyor ve bir araya geliyorlar. Bu süreçte çoğu özcü nitelikli Tanrıça miti söylemleri, feminizm ve fitness gibi unsurlar oryantal dansın üretim ve tüketim kalıplarını oluşturarak, kadınlar açısından muğlak ve çelişkili bir güçlenme alanı yaratıyor (Keft-Kennedy, 2005: 159).

Bu süreçte, oryantal dans eğitimi alan kadınların fiziksel kapasiteleri ve kendilerini ifade etme olanakları gelişiyor, özgüvenleri artıyor. İçe dönük ve katı beden dilleri açılıp rahatlıyor. Birçok kadın açısından oryantal dans kursuna gitmek, sadece kendilerine ayırdıkları özel bir zaman dilimini; onlara gücü, macerayı ve cinselliği çok gören toplumsal ilişkilerden kaçışı, kamusal alana çıkışı ifade eder hale geliyor (Deagon, 1999: 3). Ayrıca birçok Amerikalı kadın için bu dans, pozitif beden imgesi, şifa, bir topluluğun parçası olma hissi, stres kontrolü, özgüven, fitness ve maneviyatı (spritüelliği) temsil ediyor (Banasiak, 2018: 29).

Kadınların bu dansa ilgi duyma sebepleri de çeşitlilik kazanıyor: fiziksel ve psikolojik rahatsızlıklardan kurtulmak, ortaklık duyulan kadınlarla bir arada olup bir tür kızkardeşlik hissi yakalamak; mutlu, sağlıklı ve güçlü hissederek güçlenmek ve maneviyat. Batılı kadınlar arasında bu şekilde popülerleşen oryantal dans, zamanla kadınlar ve bedenleri hakkındaki toplumsal ve kültürel normlara karşı bir tür direniş formuna dönüşmeye başlıyor (Moe, 2012'den akt. Banasiak, 2018: 29).

Oryantal dansla ilgili çoğu Batılı, orta sınıf, beyaz kimliklere sahip bu kadınların deneyimlerini eleştirel bir biçimde inceleyen başka araştırmalar da bulunuyor. Bu çalışmalarda, Kuzey Afrika ve "Ortadoğu”da ortaya çıktığı kabul edilen ve günümüzde çok daha geniş bir coğrafyaya yayılan bu dans türünü sahiplenerek kendine mal etme; Batı merkezci, ötekileştirici, hatta sömürgeci yaklaşımlar geliştirme gibi eğilimlere yönelik eleştirel analizler öne çıkıyor. ${ }^{6}$ 
Türkiye bu dans türünün temel coğrafyalarından biri kabul edilmesine rağmen, Türkiye'de 1980'li yıllardan itibaren gelişen feminist hareket içinde, oryantal dansın ya da başka bir dans ya da hareket türünün popülerleştiğini göremiyoruz. Bununla birlikte, tarih ya da coğrafyadan bağımsız bir şekilde, kadınların bir arada oldukları, kadın kadına öğrenme ortamlarının, "eril bakışla ilişkilendirilen yargılayıcı tavırların olmadığı, korunaklı bir atmosfer sağladığını" görüyoruz (Moe, 2015: 7). Bu tür ortamlar, "kadınların bedenleriyle ilişkilerini kendilerinin tanımlamasını” kolaylaştırıyor. Deneyimlerin benzerliği, muhtemelen kadın ortamlarının sağladığı bu göreceli "rahat" ortamdan kaynaklanıyor. Dans stüdyosundaki aynadan kendi bedenine bakan birçok kadın, bu deneyimin -özellikle kadınların yargılayıcı olmayan, aksine destekleyici olan tavırları söz konusu olduğunda- oldukça güçlendirici olabildiğini ifade ediyor (Moe, 2015: 8). Oryantal dansı kamusal ortamda, belli bir seyirci kitlesi karşısında icra etmenin oluşturacağı sınırlamalardan kurtulmak, kadınların kendilerinden beklendiği gibi değil, kendi istedikleri şekilde hareket etmelerine olanak sağllyor. Tabii ki tüm bunlar, oryantal dans dersinin bir çeşit feminist ütopya alanı olduğu anlamına gelmiyor. Bununla birlikte, Batılı kadınların kendilerine dayatılan bedenle ve fiziksellikle ilgili normların dışına çıkma olanaklarını ortaya koyuyor (Moe, 2015: 14).

\section{Sonuç}

Oryantal dansla tanıştığım 2018 yılından bu yana araştırmacı-dansçı, dramaturg, öğrenci vd. rollerle ve feminist ilkelerle yürüttüğüm araştırmalar, sanatsal ve akademik üretim olarak ayrılan alanların iç içe geçmesini, birbirini besleyip zenginleştirmesini sağladı. Kişisel deneyimlerim, farklı coğrafyalardan gelen, çok farklı kimliklere sahip kadınların deneyimleriyle buluştu. Farklı ülke ve şehirlerdeki sanatsal üretim süreçlerinin, kültürlerarası etkileşimin ve karşılaştırma olanaklarının da etkisiyle, çalıştığım farklı alanlara yönelik bakışım gelişti. Araştırma sürecince karşılaştığım birçok kadın deneyimi ve erişebildiğim geniş akademik literatür, beni üç sene önce hayal edebileceğimden çok daha geniş bir çalışma alanına kavuşturdu.

Dünyanın çoğu yerinde akademik alanda temsil edilmeyen, kurumsal eğitim olanakları oldukça sınırlı olan, çoğu zaman hor görülen, bununla birlikte özellikle kadınlar tarafından sahiplenilen küresel bir dans türü haline gelmiş olan oryantal dans, özellikle sömürgecilik sonrası feminist çalışmalar için çok zengin ve verimli imkânlar sunuyor. Farklı kadın deneyimleri; yargılayıcı, ötekileştirici, sınırlayıcı bakışlardan uzak bir şekilde icra edilen dans türlerinin özgürleştirici boyutları olabileceğini ortaya koyuyor. Bu alanda çalışan farklı kimliklere sahip kişilerin deneyimlerini incelemek, bunları karşılaştırmalı bir şekilde, farklı toplumsal bağlamları gözeterek değerlendirmek birçok eleştirel ve alternatif üretimin kapısını aralayabilir. Oryantal dans alanında yeni sahneleme imkânları, pedagojik yaklaşımlar, yayın olasılıkları yaratılabilir. Farklı deneyim ve tahayyüllerle bir araya gelinip perspektifler zenginleştirilebilir, alternatifler oluşturabilir. Bu tür üretimlerin, herkesin kendini özgürce ifade edebileceği sanat ortamlarına ilham vermesi mümkündür. Bu makale de bu hayalin mütevazı bir ifadesi olarak kaleme alınmıştır. 


\section{Notlar}

1 Bu dansı Türkçede “oryantal dans”, İngilizcede "belly dance” (Türkçesi "göbek dansı") olarak adlandırıyorum. Anlaşılır olmak adına, her iki dilde de en yaygın olan terimleri tercih ediyorum. Bu dansa yönelik terminoloji, oryantalist, sömürgeci ve cinsiyetçi bir tarih içinde şekillendiği için ciddi sorunlar barındırıyor. Ben de başka birçok araştırmacının yaptığı gibi terimi hak ettiği şekilde, yani aşağılayıcı olmayan bir biçimde kullanarak, anlamını iade etmeyi tercih ediyorum. (Bkz. Karayanni, Stavros Stavrou. (2004). Dancing fear and desire: Race, sexuality and imperial politics in middle eastern dance, Canada: Wilfrid Laurier University: 27 ve Deagon, A. (1999). Feminism and Belly Dance, Habibi. 17.4: 8-13. Erişim tarihi 25.02.2021, http://people.uncw.edu/ deagona/raqs/feminism.htm

Terimin tarihçesine dair eleştirel bir çalışma için ayrıca bkz. Hawthorn, Ainsley. (2019). Middle eastern dance and what we call it, Dance Research 37.1 (2019): 1-17, Erişim tarihi 10.06.2019, https://www.euppublishing. com/doi/full/10.3366/drs.2019.0250

2 Araştırma sürecine dair daha ayrıntılı bilgi için bkz..... (anonimliği olabildiğince koruyabilmek için silinmiştir)

3 Bu sahneleme sürecini ve koreografinin dramaturjisini ..... başlıklı bir bildiride değerlendirdim. Bildirinin özeti şu adreste yayımlandı.... (anonimliği olabildiğince koruyabilmek için silinmiştir)

4 Ece Öztan bu tarihselliği şu şekilde özetliyor: “Özellikle 1990'lardan sonra Eleştirel Erkeklik çalışmaları alanı ile Kuir (Queer) kimlik ve araştırma alanının gelişimi beraberinde toplumsal cinsiyet araştırmaları yerine, feminist ve pro-feminist araştırma alanlarını yalnızca kadınlar ve/veya yalnızca iki toplumsal cinsiyet (kadınlık ve erkeklik) ile sınırlamayan "feminist araştırmalar" terminolojisi de yaygınlaşmaya başlamıştır. Kuir araştırmalar ile erkeklik çalışmaları ile diyaloğa dayanan bu terminoloji kimi yazarlarca daha kapsayıcı bir şemsiye terim olarak kullanılmaktadır." (Öztan, 2015: 277).

$5 \quad$..... başlıklı bir başka bildiride, oryantal dans eğitiminin üzerimdeki etkisini de kısaca değerlendirdim. Bildirinin özeti şu adreste yayımlandı..... (anonimliği olabildiğince koruyabilmek için silinmiştir)

$6 \mathrm{Bu}$ eleştirileri bir araya getiren bir çalışma için bkz. Hooi, Mavis. (2015). Oriental fantasy: a postcolonial discourse analysis of western belly dancers' 1maginations of egypt and dance festivals in egypt", lisans bitirme tezi, Linköpings University, Erişim tarihi 01.03.2021, http://liu.diva-portal.org/smash/get/diva2:907053/FULLTEXT01.pdf

\section{Kaynakça}

And, Metin. (1976). A pictorial history of Turkish dancing. Ankara: Dost.

Birkalan-Gedik, H. (2009). Türkiye'de feminizmi ve antropolojiyi yeniden düşünmek: Feminist antropoloji üzerine eleştirel bir deneme. Cogito, sayı: 58 (Feminizm özel sayıs1): 285-338.

Deniz, A. 2020). Bedenden mekâna taşan iktidara özdüşünümsel bir bakış: Heteroseksüel bir kadının lgbti bireylerin Ankara'sına yolculuğundan notlar (E. Erdoğan ve N. Gündoğdu, Ed.) Türkiye'de feminist yöntem içinde (232-250). İstanbul: Metis.

Erdoğan, E. (2020). Suçluyum, çaresizim, kızgın ve kırgınım: Feminist sahanın duyguları, gücü ve etiği (E. Erdoğan ve N. Gündoğdu, Ed.) Türkiye'de feminist yöntem içinde (278-306). İstanbul: Metis.

Grau, A. (2007). Dance, anthropology and research through practice. Re-thinking practice and theory international symposium on dance research bildiri kitabı içinde, 21-24 Haziran 2007: 2.

Moe, A. M. (2015). Unveiling the gaze: Belly dance as a cite of refuge, re-envisioning and resistance (A. Trier-Bieniek. Ed.) Feminist theory and pop culture içinde Rotterdam, Boston, Taiepi: Sense: $1-17$.

Öztan, E. (2105). Feminist araştırmalar ve yöntem (F. Saygılıgil. Ed.) Toplumsal cinsiyet tartışmaları, Ankara: Dipnot: 271-289.

Öztürkmen, A. (2011). Türk usulü modern dans, cumhuriyetin ilk y1llarında Osmanlı dansının dönüşümü (G. Ertem, Ş. Selışık Aksan. Ed.) Yirminci yüzyılda dans sanatı: Kuram ve pratik içinde, Boğaziçi Üniversitesi.

Öztürkmen, A. (2003). Modern dance "alla Turca": Transforming Ottoman dance in early republican 
Turkey". Dance Research Journal, 35, 38-60.

Öztürkmen, A. (2001). Politics of national dance in Turkey: A historical reappraisal. Yearbook for Traditional Music, 33: 131-135.

Potuoğlu-Cook, Ö. (2006). Beyond the glitter: Belly dance and neoliberal gentrification in Istanbul. Cultural Anthropology 21.4: 633-660.

\section{Elektronik kaynaklar}

Banasiak, K. N. (2018). Make your belly dance. An exploration offeminism, orientalism, and embodiment in the lived experience of belly dance. yayımlanmamış doktora tezi, York Üniversitesi, Erişim tarihi 10.02.2021, https://yorkspace.library.yorku.ca/xmlui/bitstream/handle/10315/34974/Banasiak_Krista_2018_PhD.pdf?sequence=2\&isAllowed=y

Keft-Kennedy, V. (2005). Representing the belly-dancing body: Feminism, orientalism, and the grotesque, yayımlanmamış doktora tezi, Wollongong Üniversitesi, Erişim tarihi 06.06.2019, https://ro.uow.edu.au/theses/843/

Shay, A. ve Sellers-Young, B. (2003). Belly dance: Orientalism-exoticism-self-exoticism, Dance Research Journal, 35, 1: 13-37, Erişim tarihi 19.01.2018, http://www.jstor.org/ stable/1478477

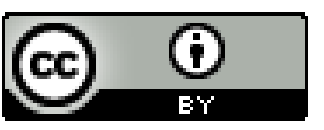

Bu eser Creative Commons Atıf 4.0 Uluslararası Lisansı ile lisanslanmıştır. (This work is licensed under a Creative Commons Attribution 4.0 International License). 